How to cite this article:

Duraisingam, T. J., Tee Say, K., \& Muniandy, S. (2020). Rule of law, stateless Indians and employment rights. UUM Journal of Legal Studies, 11(1), 51-73. https://doi.org/10.32890/uumjls.11.1.2020.5717

\title{
RULE OF LAW, STATELESS INDIANS AND EMPLOYMENT RIGHTS
}

\section{${ }^{1}$ Tamara Joan Duraisingam, Kuek Tee Say \& Saratha Muniandy}

Taylor's Law School, Taylor's University, Subang Jaya, Malaysia

${ }^{1}$ Corresponding author: tamarajoan.duraisingam@taylors.edu.my

Received: 14/1/2019 Revised: 5/92019 Accepted: 15/1/2020 Published: 31/1/2020

\begin{abstract}
This paper focuses on the Rule of Law and its reach in terms of the stateless Indian in Malaysia. The term rule of law has been used by politicians to secure political mileage during election campaign periods and continues to be used upon formation of a new government. Regardless of its transcendent nature and noble assurance of a government of laws and not men, there would be gaps in the usage of the term rule of law as it does not reach all levels of community. As beneficent as the concept maybe, it does not serve to assist the stateless Indian community in securing employment in the state. Hence the significance of the research is to identify the gaps in the application of Rule of Law in Malaysia towards the stateless Indian. This study is a purely conceptual one which evaluates the constitutional concept of rule of law and its limitations in providing employment rights for stateless Indians. The predominant research question is whether the Rule of Law as understood by constitutional philosophers helps mitigate the plight of the stateless Indian. It investigates the notion that perhaps stateless Indians are not stateless after all but have been given that categorization so as to allow for their plight to be catapulted into the international sphere where customary international law and treaty law could in ideal
\end{abstract}


circumstances, apply to the stateless Indians. It proposes a thesis that regardless of how closely a state like Malaysia follows and upholds the rule of law, the stateless Indian community in Malaysia will not necessarily enjoy second generation rights that ought to be made available to all human beings. The second-generation rights specifically referred to in this research is the right to employment for the stateless Indian.

Keywords: Stateless Indian, Rule of law, Employment rights, Concept promulgated.

\section{INTRODUCTION}

Despite the fact that the concept is archaic, the rule of law is very much alive in the Malaysian political scene and has been a concept promulgated by politicians, both governmental and opposition members of Parliament to demonstrate their sincerity as the beacon of hope for Malaysian citizenry. The question lies as to whether such concepts used so generously can in fact metamorphose into a mature system of law that protects citizens and non-citizens alike. The focus of this doctrinal paper is the concept of rule of law. Integrative literature on domestic and international understanding of rule of law as well as the law on stateless persons is demonstrated through the article. The rule of law is tested against Indians who have been living in this country from before independence but have failed to acquire citizenship in the country. The particular right referred to in this analysis is the right to employment which is a fundamental economic right of all human beings. Constitutional provision on the right to life in Malaysia possibly includes the right to livelihood. The question to be answered is whether the rule of law is able to reach as far as to ensure that non-citizen Indians are able to exercise their right to employment in Malaysia. Lord Bingham's definition of Rule of Law (Bingham, 2011) is used as a litmus test to determine the reach of Rule of Law for the stateless Indian residing in Malaysia. Doctrinal evaluation of the rule of law is employed coupled with basic presumptions that will form the base for future qualitative research in this area of law. The incidental questions that are answered are whether these individuals are in fact stateless according to international law, thereby entitling them to international 
law protection. The research rests upon the thesis that although noncitizen Indians residing in Malaysia do not benefit from all rights made available to citizens, overall, they do benefit from the reach of constitutional law concepts such as rule of law.

\section{METHODOLOGY}

This paper is a conceptual piece that aims to evaluate the current notion of rule of law as proclaimed by the current Premier of Malaysia in his inaugural speech to his 'rakyat' on 10 May 2018 (Berita Viral, 2018). The paper draws from doctrinal analysis of the concept and its application to the non-citizen Indian community in Malaysia. There is a need to evaluate the effectiveness of the concept as it applies in Malaysia and identify areas that the concept fails to reach. Yaqin (2007) states that the underlying target of such research is to gain and present new knowledge and ideas or to suggest change and reform. For purposes of this research, the idea is to demonstrate the reach of rule of law and propose solutions as to how the concept can extend to all communities even the non-citizen Indian community. Barnett's (2017) works on the rule of law is used as the platform to develop an understanding of rule of law in general and compare it to the non-citizen Indian community within the Malaysian context. Lord Bingham's eight principles of rule of law are used as a benchmark to determine the areas in which Malaysia has succeeded in upholding the Rule of Law specifically for the stateless Indian.

Secondary data on the plight of the non-citizen Indian community will be gathered and analyzed in a manner that juxtaposes with the concept of rule of law. The secondary data provides information on the plight and employment prospects of the non-citizen Indian community in Malaysia. Here heuristics is used to discover the problem with the concept of rule of law as it applies today and to resolve the problem using a rule-of-thumb procedure. The sample population in which this procedure will be used is the non-citizen Indian community residing in Malaysia. The view is that such ruleof thumb procedure would benefit other stateless communities in Malaysia as well. The doctrinal research forms the base from which further qualitative research will be conducted in this area to determine the situation in the field. 
The sample population chosen for this paper is the non-citizen Indian communities who have been residing in Malaysia from before independence for namely two reasons:

1. Issues of statelessness have arisen for 'pre-merdeka' stateless Indians. The question of citizenship has been an issue of contention for a longer period compared to others who may be deemed stateless.

2. The previous government has effectively begun efforts to register all stateless Indians (stateless being the term used by the previous government) as citizens of the State. Hence a structure to remedy the situation is already in place. These efforts are being continued by the current government. Time becomes of the essence for this community. As such it is best to begin with the community whose issues relating to citizenship are on the way to recovery and work backwards.

Relevant legal sources such as the Federal Constitution of Malaysia 1957, the Immigration Act 1959 (ACT 155) and Births and Deaths Registration Act 1957 are applied as the legitimate platform that forms the subject matter of discussion within the context of Rule of Law and the Stateless Indian. This is buttressed by case law which either directly or indirectly upholds the concept of Rule of Law.

Apart from which, the historical approach involving objective study of past facts (Yaqin, 2007) is useful to determine how and why citizenship has not been accorded to certain persons of Indian origin. This coupled with the observation of current norms assist in elucidating the issues and paving the way for appropriate recommendations.

Quite a few limitations have surfaced in the effort to conduct this research. Firstly, commentators are critical of doctrinal research and view it in a negative light using the term 'armchair' research which implies that the researchers are detached from the aggrieved population. It has been suggested that there is a realization that research studies in the field of law ought not to be confined to pure legal matters. According to Manly and Van Vaas (2014), it is increasingly evident that the study of statelessness ought to evolve beyond law. Nevertheless, the researchers are of the view that 
doctrinal research is more suitable in instances where the focus of the research lies in the constitutional concept rather than the population. In strengthening the understanding and application of rule of law in the State, problems such as statelessness may perhaps be avoided or remedied by rule of thumb procedure.

Confining the issues of statelessness is actually limiting its complexity. Individuals in society hope to achieve not only legal recognition but also social, political and moral recognition (Reddy, 2015). Legal triumphalism ${ }^{4}$ allows for documentation to prove identity. This in itself is a cumbersome formulation and does not do much in terms of political, national and regional belonging (Allerton, 2017). Wider research ought to be conducted in collaboration with social scientists to provide holistic support for this community.

There is confusion as to whether a non-citizen Indian residing in Malaysia is in fact stateless. At first, the view of the researcher was that this group of individuals did fall under the category of de facto statelessness. As the international law definition on statelessness itself developed over the years, the notion today would be that this group is merely not documented and only communities like the Rohingya community residing in Malaysia are de jure stateless. Perhaps a clearer account on who is stateless according to international law would strengthen research in this area as it can then form the common basis for discussion (Manly \& van Waas, 2014). The current domestic understanding however is that Indians without documents are stateless whereas Indians with red identity cards (ICs) are not categorized as stateless but having documentation issues (Prime Minister's Office, 2017). Hence a dichotomy arises within international and domestic perspectives as to who is a stateless Indian. The most accurate phrase to be used to categorise this group of individuals would be "the non-citizen Indian who has been residing in Malaysia since before independence and his / her lineage is born in Malaysia which in itself is a mouthful. In any case, mere categorization is seen to be an inept method of clarifying things. The more appropriate approach would be to accept the notion of statelessness in all its permutations thereby benefitting all Indians affected by lack of documentation. As such, the research paper uses either the terms, non-citizen Indian or stateless Indian interchangeably. 


\section{The Stateless Indian}

Stateless Indians are currently defined through the interpretation of the Malaysian Indian Blueprint 2017 as Indians who have arrived in Malaysia before independence, have raised children in the State but have failed to acquire citizenship in the State. Stateless Indians encompass those with no identification documents. This definition has not been easy to obtain. It principally refers to the domestic understanding of statelessness. To understand how this has been derived, both international and domestic laws become relevant.

\section{Article 1 of the Convention relating to the Status of Stateless}

Persons 1954 defines a 'stateless person' as 'a person who is not considered as a national by any State under the operation of its law.' Although Malaysia is not party to the Stateless Persons Convention, the convention is important as the term stateless person is a term coined by international law and not domestic law. Since this term has been used for Indians without birth certificates in this country under the Malaysian Indian Blueprint, it becomes crucial to define statelessness within international terms.

Malaysia uses the operative term of citizenship rather than nationality under Article 14 of the Federal Constitution. Malaysia provides for citizenship by operation of law to anyone born in the Federation from Merdeka Day, which was 31 August 1957 till the end of September 1962 under Article 14, 2nd Sch, Part I Federal Constitution of Malaysia 1957. The constitution also grants nationality to those born after September 1962 if either parent is a citizen or permanent resident in its Article 14, 2nd Sch, Part II. Indians who arrived during the British era are entitled to citizenship. The spirit of the law seems to provide for this privilege. However, the letter of the law with the inclusion of the terms, 'citizenship' by 'operation of the law' causes uncertainty. The Births and Deaths Registration Act 1957 requires the birth to be first registered before citizenship can take effect. Secondly upon achieving independence, the then New Government had begun a work permit system in which labourers were meant to register first in order to acquire citizenship later. At least one fifth of the Indian population had failed to acquire the work permit (Prime Minister's Office, 2017). These requirements provided hurdles to automatic citizenship. 
For children born post September in 1962, the jus sanguinis rule applies which makes it more arduous for children to acquire Malaysian citizenship. Indian children suffer the brunt of customary marriages that still exist in Malaysia. One of the requirements for the issuance of a birth certificate is a marriage certificate or any legal document as proof of marriage of the parents. If the parents themselves have not registered their marriage, the child may be denied a birth certificate. The case of Nalan a/l Kunji Kanan \& Anor v Secretary General of the Ministry of Home Affairs, Malaysia \& Ors ${ }^{1}$ Kamaludin Md. Said J stipulated that the birth of the plaintiff (in this case a non-citizen Indian) is premised on the core issue of whether his biological mother and father were properly and legally married under the law. Such information was lacking in this particular case which was one of the factors that led to a dismissal of the case with no resolution as to the plaintiff's citizenship status.

Registration of marriage, on the other hand, is impossible if one of the parents is already married. Before the Law Reform (Marriage and Divorce) 1976 Act was enforced, it was common for Indian men to have a second wife through customary marriage. Cases on customary marriages have been determined in local courts (see: Kausalya a/p M. Pathmanathan \& Kavitha a/p Pathmanathan ${ }^{5}$ The Legal Representatives of Jamuna a/p Narayanan and Jayaselan a/l M. Pathmanathan). Though the law has been changed, second customary marriages within the Indians practising Hinduism could still take place as Hindu law does recognise polygamous marriages as was enunciated by Hishamudin Yunus JCA in the above case. The result is that children born of that marriage may not have their births registered.

What surfaces from these observations is that the entitlement to nationality is not eradicated due to lack of procedural compliance. The Federal Constitution provides for citizenship rights for Indians born in the country from the time of independence onwards. If Indians in Malaysia are considered to be stateless, they are stateless as of fact not as of law. Indians in Malaysia without birth certificates

1 Nalan a/l Kunji Kanan \& Anor v Secretary General of the Ministry of Home Affairs, Malaysia \& Ors, [2017] MLJU 1808

2 Kausalya A/P M. Pathmanathan \& Kavitha A/P Pathmanathan v The Legal Representatives of Jamuna A/P Narayanan and Jayaselan A/L M. Pathmanathan, Civil Appeal No. X-02(NCVC)(W) - 1408-06/2012. 
may fall into this category of de facto statelessness. Protection for this group of individuals is not provided for within international law. The Stateless Persons Convention 1954 refers to statelessness de jure. The concept of de facto statelessness is not contained in the articles of the Stateless Persons Convention but is provided for in the Final Act. The Final Act of the Convention merely recommends that States party extend the provisions of the Convention to de facto stateless persons whenever possible.

There is also argument to say that even de facto statelessness does not at all apply to the Indians without birth certificates in Malaysia. Hugh Massey analyzed the concept of de facto statelessness in the following terms:

De facto stateless persons are persons outside the country of their nationality who are unable or, for valid reasons, are unwilling to avail themselves of the protection of that country.

Persons who have more than one nationality are de facto stateless only if they are outside all the countries of their nationality and are unable, or for valid reasons, are unwilling to avail themselves of the protection of any of those countries (Massey, 2010).

Massey's definition of de facto statelessness was adopted as part of the Summary Conclusions to the Prato Expert Meeting which provided for definitions on the categories of statelessness (UNHCR, 2010). Depending on how one interprets the concept of statelessness, Indians without proper documentation may not be entitled to find shelter within the cloak of international law, placing the issue of Indian possible statelessness within the purview of domestic law. Whilst the Malaysian Indian Blueprint refers to the stateless Indians as those not holding any identification documents and are not considered citizens by any nation (Prime Minister's Office, 2017), international law may only refer to this group of individuals as undocumented or potentially stateless (UNHCR, 2010).

As such, the interpretation of law within the concept of rule of law for our purposes encompasses only domestic law. Whilst international law provides rights to all stateless individuals, domestic laws may not be all that clear. There may be instances where Indians without documentation are disadvantaged as only the citizen is free from 
discrimination with regards to trade, business, profession, vocation or employment (Art 8 [2], Federal Constitution of Malaysia). Without proper documentation, Indians can only secure informal work. Without being governed by contractual terms, Indians without citizenship do not benefit from security of tenure and are unable to register businesses of their own.

Very positive steps have been taken by the former government to eradicate the issue of statelessness as is understood based on national policy. Efforts were made to open up special National Registration Department Counters under the national campaign, My Daftar, first held between 19 to 26 February 2011. A total of 4,023 applications for citizenship were approved through this campaign, by the government within a year. ${ }^{6}$ According to the Development of Human Resources for Rural Areas (DHRRA) as of 2017, an estimated 12,300 Indians are currently stateless (Prime Minister's Office, 2017).

On August 13, 2018, it was announced by the Pakatan Harapan government that 3407 Indians aged 60 and above would receive their citizenship status (Alagesh, 2018). One of the key aspects of the Pakatan Harapan manifesto was to resolve statelessness within the Indian community in Malaysia. Hence tangible governmental efforts to eradicate statelessness exist.

\section{RULE OF LAW}

The term rule of law is a fluid term that has been used generally to depict the notion of a government of laws and not of men. The Eastern understanding of rule of law focuses on the duty of citizens to obey the law, whereas the Western notion of rule of law incorporates human rights as part of its interpretation. Lon Fuller (as cited in Barnett, 2017) focuses on the 'morality of the law.' According to Fuller, a government must seek to provide the environment in which each citizen may realize his or her maximum potential in living a

\footnotetext{
Datuk Seri Najib Tun Razak. (2013). Najib says my daftar campaign organised by MIC is unique and special. Retrieved from http: //www.1Malaysia.com. my/news_archive/najib-says-mydaftar-campaign-organised-by-mic-is-uniqueand-special
} 
life which he or she aspires. Society must be free and directed to the good of each of its members. Any government which fails in a material degree to meet these requirements may fail to deserve the label of a 'legal system' according to Fuller. Applying Lon Fuller's perspective, the question arises as to whether all citizens in Malaysia are able to maximize their potential by virtue of a legal system which caters for the potential of the citizen. Taking this rule further, would this include the stateless Indians who historically ought not to be deemed stateless in Malaysia as their arrival took place before independence? An analysis on Bingham's perspective on the Rule of Law (as follows) using the stateless Indian as the focus of the study provides further illustration on morality of the law within the Malaysian legal system.

Lord Bingham provided a neat account on rule of law, encompassing eight aspects: clarity and accessibility of the law; resolving issues via the law rather than discretion; equality of the law; protection of human rights; resolution of disputes; exercise of power in good faith; fair trial and the compliance with international law obligations (Bingham, 2011).

The term rule of law however has been a term used by politicians to secure political mileage during election campaign periods and continues to be used in that manner. According to (Robson, 2004), the term is so frequently used by constitutional players such as politicians, lawyers and judges as well as the media that it borders on being one of those common irritating phrases used. Humphreys (as cited in Cheesman, 2014), considers rule of law as 'a blanket term intending to cover multiple public goods, "the rule of law" is overused, of limited analytic or descriptive value, and potentially distorting.' To date the concept of rule of law has not been used directly in connection with stateless Indians. The term is used in an overarching manner. Nevertheless, the term has been used in UK administrative law decisions. In Bradbury v London Borough Council $^{7}$, Lord Denning did enunciate that local authorities are subject to the rule of law and that it is important to uphold the rule of law. Although the rule of law is a constitutional law concept, it can be used in judgements within a specific context.

According to Hutchinson, in spite of the rule of law being criticized by

4 Bradbury v London Borough Council [1967] 1 WLR 1311 
some as meaningless, irritating, overused and distorting, it remains a term that invigorates systems of law and applies as a beacon of hope and transcends all partisan concerns $(1987$, p. 9).

In Malaysia, the Federal Constitution serves as the apex law of the land. Rights within the Federal Constitution however are contained in Articles 5-13. These provisions have specific limitations. Firstly, the fundamental liberties enshrined in Part II of the Federal Constitution do not cover all 1st and 2nd generation human rights which are available under contemporary international human rights law. The Western understanding of rule of law encompasses the realization of civil and political rights as well as economic, social and cultural rights.

Although not inclusive of all available rights, those covered in the Federal Constitution provide an interesting mixture of both civil and political rights as well as economic, social and cultural rights. These include liberty of the person (Art 5), rights against slavery and forced labour (Art 6), protection against retrospective criminal laws and repeated trials (Art 7), equality before the law (Art 8), prohibition of banishment and freedom of movement (Art 9), freedom of speech, assembly and association (Art 10) freedom of religion (Art 11) rights in respect of education (Art 12) and rights to property (Art 13). Rights such as the right to wage earning employment, social security or to marry and found a family are not directly provided for within the Federal Constitution.

Secondly, some rights are only available to citizens. For example, the right to education under Article 12 of the Federal Constitution is available only to citizens. Only the Articles 5, 6, 7, 8, 11 and 13 are potentially available to all persons. Hence the stateless Indian may fall out of the equation because they do not have formal citizenship in the State. They may not be benefactors of all the rights contained in the Federal Constitution.

In theory, it seems clear that Rule of Law is embodied in our legal system. Article 4 of the Federal Constitution clearly states that the Federation of Malaysia subscribes to supremacy of the constitution. Cases on an extended interpretation of the right to life to potentially include the right to livelihood such as Tan Tek Seng v Suruhanjaya 
Perkhidmatan Pendidikan ${ }^{8}$ and Muhamad Juzaili bin Mohd Khamis and Ors $v$ State Government of Negeri Sembilan and Ors ${ }^{9}$ show proof of how the courts of Malaysia guard the Rule of Law. However, according to Masum (2009) in distinguishing theory from practice it remains moot as to whether the Rule of Law is embodied through the Federal Constitution. ${ }^{10}$ Masum further prescribes that it is a value to be maintained but not an absolute one ${ }^{11}$ which tends to give way to other governmental necessaries such as laws to combat subversion (Article 149) or use of emergency power (Article 150). Interpretation of the right of livelihood has yet to be stretched to provide for the stateless Indian the right to livelihood within the State. Case law developed refers to citizens of the State. Nevertheless, liberal interpretation of the fundamental liberties bodes well with the thick embodiment of rule of law within the State.

Rule of law is also to be looked at within the context of international law. In the 2004 Report of the Security Council on the Rule of Law and Transitional Justice in Conflict and Post Conflict Societies, the then Secretary General Kofi Annan (2004) stated that the rule of law was a concept at the very heart of the [United Nations] mission (UN Doc. S/2004/616). States tend to refer to either a thick or a thin

understanding of rule of law. A thin understanding simply means that a state is governed by law, whereas a thick understanding would incorporate ideal conceptions such as equality, justice and human rights. Naturally international law seeks to employ the thick understanding of rule of law. Commentators of international law prescribe three important matters within a thick list on rule of

law: certainty of the law; equality of the law and compliance of

Tan Tek Seng v Suruhanjaya Perkhidmatan Pendidikan [1996] 1 MLJ 261

6 Muhamad Juzaili bin Mohd Khamis and Ors v State Government of Negeri Sembilan and Ors [2015] 3 MLJ 513

7 Masum, A. (2009) "The Rule of Law Under the Malaysian Federal Constitution." Malayan Law Journal. c - cxx, p. 106.

8 Masum 2009: cviii. Masum, A. (2009) "The Rule of Law Under the Malaysian Federal Constitution." Malayan Law Journal. c - cxx, p.108. 
the law within the domestic and international spectrum. The third requirement would inadvertently call for independent and impartial courts and tribunals (Keith, 2015). These rules are neatly aligned with the Diceyan postulates of rule of law which are: 'no man can be punished unless there is a clear breach of law, equality of law and our rights are safeguarded by common law' (Dicey, 1982).

The Delhi Declaration ${ }^{12}$ lends clarity to the substantive focus being an inclusion of an all-encompassing entitlement of rights, be it economic, social and cultural rights as well as civil and political rights. This inadvertently leads to the opinion that States that are party to the International Covenant on Civil and Political Rights 1966 and the International Covenant on Economic, Social and Cultural Rights potentially would be the beacon states in upholding the rule of law.

According to David and Brierley, this conflict with the oriental view on rule of law which prefers the focus to be on duties and responsibilities rather than rights per se $(1985$, p. 442). As the philosophical standpoint differs, some developing States have not acceded to the human rights covenants. Malaysia for one is still shying away from the prospect of accession to either of the covenants. As such, the international law perspective of rule of law may not apply to Malaysia and the stateless Indian is eschewed from benefitting from international law.

When the Malaysian executive fiat refers to rule of law, it begs the question as to whether the thin or the thick perspective applies. The thick perspective provides more credence to the view that non-citizen Indians will be provided with rights and be subject to responsibilities as every other citizen. The thin perspective neatly confines the parameters to the letter of the law and interpretation of it. Communities with uncertain status in the State including the stateless Indian would benefit from the thick interpretation of the law.

History and politics inform us that for some time at least, juxtaposing

9 A Report on The International Congress of Jurists, New Delhi, India. (1959, January 5-10). Retrieved from https://www.icj.org/wp-content/uploads/1959/01/ Rule-of-law-in-a-free-society-conference-report-1959-eng.pdf. 
international and domestic standards of rule of law, Malaysia employs the thin perspective. Therefore, the avenue for the stateless Indian to the right to employment is currently dependent on liberal interpretation of domestic law.

\section{LORD BINGHAM'S RULE OF LAW}

Applying rule of law within the context of the stateless Indian in general terms, it remains unclear how the rule of law as it stands provides for the community. Using Lord Bingham's understanding of rule of law as a yardstick as to where Malaysia stands, provides a clearer conceptual understanding of how the rule of law has benefitted the stateless Indian, the following propositions are formed:

Rule 1 - The law must be accessible and, so far as possible, be intelligible, clear and predictable

Article 14 as mentioned in the earlier passage provides for citizenship by operation of law. The law in itself is clear and can be made predictable provided the constitutional players who utilize the law do so clearly. Difficulties in acquiring the necessary documentation such as a work permit or even a birth certificate especially for pre-merdeka stateless Indians are remedied through assistance rendered from various quarters including governmental and nongovernmental organizations. Non-governmental organizations such as Development of Human Resource for Rural Areas (DHRRA) work to eradicate statelessness within the Indian community and act as the conduit between law and its application demonstrating that the channel is available for the law to be intelligible to the stateless Indian.

\section{Rule 2 - Questions of legal right and liability should ordinarily be resolved by application of the law and not by the exercise of discretion}

Since there are no laws that confer specific protection to stateless persons or refugees, they fall under the State's immigration legislation. The Immigration Act itself in its Section 55 provides for the exemption of certain individuals from immigration laws (Immigration Act 1959 [ACT 155]) The Minister may exercise his 
discretionary power and exempt persons considered to be refugees or stateless persons. This exercise of discretionary power has led to ad hoc policies, being created over the years. Discretionary protection has been given to for example, the Vietnamese in the 1970s and the Bosnians in the 1990s. This form of discretion may lead to arbitrariness if left unchecked by international law.

Although immigration laws do not apply to the stateless Indian community due to the historical underpinnings of their status in Malaysia, nevertheless, the apex law of the land provides discretionary power that can be used for the benefit of a child. Article $15 \mathrm{~A}$ of the Federal Constitution gives the Executive discretionary power to register children (under the age of 21). Courts have been reluctant to encroach on this domain of the Executive (Nalan a/l Kunji Kanan \& Anor v Secretary General of the Ministry of Home Affiars, Malaysia \& Ors). ${ }^{13}$ Nevertheless safeguards are in place to ensure there is scrutiny of governmental exercise of discretion. In the case of Madhuvita Janjara Augustin v Augustine a/l Lourdsamy $\&$ Ors $^{14}$ it was decided that although the courts are slow to enter into cases of immigration and citizenship due to its policy, political and administrative considerations, none of the earlier case law cited those matters as non-justiciable. Although there is exercise of discretion, this is counterbalanced by the possible review of such executive decisions.

\section{Rule 3 - The law should apply equally to all, except to the extent that objective differences justify differentiation}

Objective differences in communities living in Malaysia make way for acceptable differentiation. Referring to the Orang Asli community that have also had to address this issue of potential statelessness, The Aboriginal Peoples Act 1954 (Act 134) provides authority to Jabatan Kemajuan Orang Asli (JAKOA) to safeguard the welfare of the Orang Asli. Article 8 (5) (c) of the Federal Constitution allows for protection, well-being and advancement of the Orang Asli. The Orang Asli is the only group of people indigenous to Peninsular

10 Nalan a/l Kunji Kanan \& Anor v Secretary General of the Ministry of Home Affairs, Malaysia \& Ors [2017] MLJU 1808

11 [2018] 1 MLJ 307 
Malaysia who are officially under the authority of a government department. This paternalistic approach albeit with its demerits, also can be looked at in a positive light when it comes to the acquisition of citizenship, as through this department, issues of potential statelessness within the community is remedied. On the other hand, the Rohingya community in Malaysia falls within the other end of the spectrum whereby they do not have recourse to citizenship or any right within the country and have to rely on the UNHCR for provision of assistance. While the former relies on the domestic department of government and the latter on an international organization, stateless Indians fall somewhere in between with ad hoc committees that come to their aid such as the Special Implementation Task Force that was established by the former government (Malaysian Indian Blueprint). There are objective differences within the communities as one cannot compare the Orang Asli community who has been in the State since time immemorial to the Rohingya community who only began arriving in Malaysia in the 1990s. Historical ties between the stateless Indian and Malaysia allow for more robust provision of citizenship or rights including employment. In a press statement early this year it was announced that the agency under the PM's department on Malaysian Indians (MITRA) have identified categories of statelessness and sourced a comprehensive solution which will be tabled in Parliament (Bernama, 2019).

\section{Rule 4 - The law must afford adequate protection of human rights}

Lord Bingham used the term human rights rather than citizen rights. Using this understanding would mean that fundamental liberties should be available to the stateless Indian. The provisions within the Fundamental liberties portion of the Constitution provide for liberties primarily to citizens. The lack of provision coupled by the fact that Malaysia has yet to accede to the Stateless Persons Convention 1954 and the Reduction of Statelessness Convention 1961 calls for unconventional interpretation of basic law. The right to employment may not be specifically available to the stateless Indian residing in Malaysia. Unless and until international treaties on human rights are incorporated into domestic law (whether it be the general human rights covenants or specific conventions such as the Stateless Persons Convention), the law does not afford adequate employment rights to the stateless Indian. Liberal interpretation of the right to life provision within the Federal Constitution provides 
some respite. In the case of Dato' Menteri Othman b Baginda and Anor v Dato' Ombi Syed Alwi b Syed Idrus ${ }^{15}$ it was emphasized that a constitution is a living piece of legislation and its provisions must be construed broadly and not in a pedantic way. This liberality may provide for rights to be made available to stateless Indians.

Rule 5 - Means must be provided for resolving, without prohibitive cost or inordinate delay, bona fide civil disputes which the parties themselves are unable to resolve

NGOs such as DHRRA assist in resolving disputes for stateless Indians. NGO intervention speeds up processes and provides clarity to the applicant for citizenship. At times, procedural hurdles faced by the Indians make it difficult for them to apply for citizenship and show proof of their entitlement to citizenship (Tikamdas, 2006). Long processing period, repeated rejections and no reasons for rejection are some of the overall gaps in procedures practised by the National Registration Department and Ministry of Home Affairs (DHRRA, 2019). Further collaborations between NGOs, the government and Human Rights Council assist in ensuring timely settlement of citizenship issues.

Rule 6 - Ministers and public officers at all levels must exercise the powers conferred on them reasonably, in good faith, for the purpose for which the powers were conferred, and without exceeding the limits of such powers

The fact that the Malaysian Indian Blueprint does provide for the stateless Indian demonstrates the recognition given to the plight of the Indians under the previous government. The new government has also pledged their support in providing citizenship to existing stateless Indians. The announcement published in the local newspapers on 13

Aug 2018 shows proof of this (Alagesh, 2018). However, it is still too early to determine whether the public authority assigned to the role of reaching out to the stateless Indians will do so based on the rules of natural justice and whether employment rights for stateless Indians will be considered as part of the agenda of the Ministry of Human Resources.

12 Dato' Menteri Othman b Baginda and Anor v Dato' Ombi Syed Alwi b Syed Idrus [1981] MLJ 29 


\section{Rule 7 - Judicial and other adjudicative procedures must be fair and independent}

There seems to be a flawed legal protection mechanism, or an abridgement of juridical personality ${ }^{16}$ within the context of migrant workers. One is able to analogize with that of the stateless Indians residing in Malaysia as well. Although used in various case law, (see: Nalan a/l Kunji Kanan \& Anor v Secretary General of the Ministry of Home Affiars, Malaysia \& Ors ${ }^{17}$, Madhuvita Janjara Augustin v Augustine a/l Lourdsamy \& Ors ${ }^{18}$; Pendaftar Besar Kelahiran, Malaysia v Pang Wee See \& Anor [2017]) the judiciary has never defined the term statelessness as it is not contained in any of the domestic law or applicable international law.

Judges have been quite liberal in cases involving stateless persons / refugees. Madhuvita Janjara Augustin v Augustine a/l Lourdsamy \& Ors, Mary Lim JCA interpreted Article 14(1)(b) read together with 1(e) broadly to include a child born of a foreign mother who was not legally married to the biological father who is Malaysian at the time of birth.

In the case of Tun Naing Oo $v$ Public Prosecutor ${ }^{19}$ (2009) the applicant, an asylum seeker from Myanmar, was charged under S.6 (1)(c) of the Immigration Act 1959/1963 for entering Malaysia without a valid pass. There was in this case some recognition of the plight of refugees in the country, as the judge revised the sentence

based upon humanitarian grounds. Judicial definition of the term 'statelessness' coupled with appropriate application would be of benefit to the stateless Indian.

13 Lilienthal, G., Ahmad, N., Dorloh, S. (2015) "Juridical Personality and Anti-Immigration Discrimination: A Socio Legal Examination in the Malaysian Context." 6 Malayan Law Journal Articles. Ixiii- xxiii, at page 21.

14 Nalan a/l Kunji Kanan \& Anor v Secretary General of the Ministry of Home Affairs, Malaysia \& Ors [2017] MLJU 1808

15 [2018] 1 MLJ 307

16 Tun Naing Oo v Public Prosecutor [2009] 5 MLJ 680 


\section{Rule 8 - There must be compliance by the state with its international law obligations}

For this particular rule one finds that Malaysia does lag behind in relation to international law on stateless persons since none of its conventions have been acceded to. Even if there is accession to pertinent conventions on human rights in general, articles in relation to acquisition of nationality tend to be reserved. Article 9 of Convention on the Elimination of All Forms of Discrimination Against Women (CEDAW) and Articles 7 and 8 of the Convention on the Rights of the Child (CRC) accord the right to nationality, respectively provided reservations to Article 9(2) of CEDAW and Article 7 of CRC are removed. The continued existence of stateless Indian children may be stemmed by the lifting of the reservation on Article 7 of the CRC.

\section{CONCLUSION}

When it comes to the conception of rule of law, commentators would argue that the thick conception of the rule of law as applied in international law ought to apply to Malaysia. Being a very young constitution, an evolution of the thin to the thick concept of rule of law will take place. In spite of accusations of its overuse and abuse, the rule of law is a sound base from which good laws can develop. Having the term rule of law used repeatedly by governmental fiat is advantageous. Categorization of this nature however, has its flaws especially if it is meant to be used as broad brushstrokes of the Malaysian legal landscape.

Examining the concept in more detail by juxtaposing with the Malaysian Indian community, the concept of law within the term rule of law is limited to domestic law. International law definition and rights prescribed based on the Stateless Persons Convention 1954 does not feature in this analysis. Even if the Indians without citizenship were considered stateless within international law, they would only be de facto stateless and not de jure stateless. The domestic law has yet to define statelessness or provide for convention rights. The former government defined and used the term 'stateless' for convenience in its categorization of Indians without documents 
or irregular documents. This is a step in the right direction and will eventually provide the conduit for Indians without citizenship to acquire suitable employment in the country. In applying Lord Bingham's ideal notion of the Rule of Law to the Malaysian system of law while 'stateless Indians' still remain outside the periphery of protective laws in the country, nevertheless the country can be seen to be upholding the rule of law. Through this doctrinal analysis, one can confirm that although non-citizen Indians residing in Malaysia do not benefit from all rights made available to citizens, overall, they do benefit from the reach of constitutional law concepts such as rule of law. The recommendation would be for the international law definition of statelessness and the processes and the rights therein would eventually need to be transposed into domestic law to ensure more effective safeguards of the law. This would be the best interim measure for all stateless individuals. Citizenship for all Indians who have been residing in Malaysia from before Merdeka and their kin would indeed be the ultimate goal as all rights can only be enjoyed when one is a citizen of a state. Fortunately, the goal of this community is aligned with that of the State and the realization of this goal has already taken shape.

\section{ACKNOWLEDGEMENT}

This research received no specific grant from any funding agency.

\section{REFERENCES}

A Report on the International Congress of Jurists, New Delhi, India January 5-10, 1959. Retrieved from https://www.icj.org/ wp-content/uploads/1959/01/Rule-of-law-in-a-free-societyconference-report-1959-eng.pdf

Aboriginal Peoples Act 1954 (Act 134).

Alagesh, T. N. (2018, August 22). Stateless Indians will soon be a thing of the past. New Straits Times. Retrieved from https://www.nst.com.my/news/nation/2018/08/404010/ stateless- indians-will-soon-be-thing-past

Allerton, C. (2017). Contested statelessness in Sabah, Malaysia:

Irregularity and the politics of recognition. Journal of Immigrant \& Refugee Studies, 15(3), 250-268. 
Barnett, H. (2017). Constitutional and administrative law (12th ed.). London, United Kingdom: Routledge Taylor and Francis Group.

Berita Viral. (2018, May 9). Breaking news! - Tun Dr. Mahathir press conference [Video File]. Retrieved from https:// www.youtube.com/watch? $\mathrm{v}=\mathrm{ONfNj}-5 \mathrm{dbz} 8$

Bernama. (2019, March 27). Comprehensive solution on the issues of stateless Malaysians, says minister. Retrieved from https://www.malaymail.com

Bingham. (2011). The Rule of Law. London, United Kingdom: Penguin.

Births and Deaths Registration Act 1957.

Bradbury v London Borough Council [1967] 1 WLR 1311.

Cheesman, N. (2014). Law and order as asymmetrical opposite to the rule of law. Hague Journal on the Rule of Law, 6(01), pp. 96-114.

Dato' Menteri Othman b Baginda and Anor v Dato' Ombi Syed Alwi $b$ Syed Idrus [1981] MLJ 29.

Datuk Seri Najib Tun Razak. Najib says my dafter campaign organised by MIC is unique and special. Retrieved from http: //www.1Malaysia.com.my/news_archive/najib-saysmydaftar-campaign-organised-by-mic-is-unique-and-sepcial/

David, R., \& Brierley, J. E. C. (1985). Major legal systems in the world today: An introduction to the comparative study of law. London: Stevens.

DHRRA Malaysia (2019). Resolving statelessness in Malaysia. Resolution Handbook. Malaysia: DHRRA Malaysia.

Dicey, A. V. (1982). Introduction to the study of the law of the constitution (Reprint) Indianapolis: Liberty Classics.

Duraisingam, T. (2016). Chronology of policies affecting potentially stateless persons and refugees in Malaysia. Institute on Statelessness and Inclusion. No. 2016/07. Retrieved from https://www.researchgate.net/publication/323469546

Federal Constitution of Malaysia 1957.

Fuller, L. (1964) The morality of law. New Haven Connecticut: Yale University Press.

Humphreys, S. (2010) Theatre of the rule of law. Cambridge: Cambridge University Press.

Hutchinson, A. C., \& Monahan, P. (1987). The rule of law: Ideal or ideology, Toronto: Carswell. 
Immigration Act 1959/63 (Act 155).

Kausalya A/P M. Pathmanathan \& Kavitha A/P Pathmanathan $v$ The Legal Representatives of Jamuna A/P Narayanan and Jayaselan A/L M. Pathmanathan, Civil Appeal No. X02(NCVC)(W) - 1408-06/2012.

Keith, K. J. (2015). The international rule of law. Leiden Journal of International Law. 28, 403-417.

Law Reform (Marriage and Divorce) 1976 Act.

Lilienthal, G., Ahmad, N., \& Dorloh, S. (2015). Juridical personality and anti-immigration discrimination: A socio legal examination in the Malaysian context. 6 Malayan Law Journal Articles. ixiii-xxiii.

Manly, M., \& van Waas, L. (2014). The state of statelessness research: A human rights imperative. Tilburg Law Review, 19(1-2), 3-10.

Massey, H. (2010). Legal and Protection Policy Research Series, UNHCR and De Facto statelessness. LPPR 10/01. Retrieved from http://www.unhcr.org/4bc2ddeb9.pdf.

Masum, A. (2009) The rule of law under the Malaysian Federal Constitution. Malayan Law Journal. c-cxx.

Muhamad Juzaili bin Mohd Khamis and Ors v State Government of Negeri Sembilan and Ors [2015] 3 MLJ 513

Nalan a/l Kunji Kanan \& Anor v Secretary General of the Ministry of Home Affairs, Malaysia \& Ors [2017] MLJU 1808

Prime Minister's Office. (2017). Malaysian Indian Blueprint. Retrieved from http://mib.my.

Reddy, M. (2015). Response to the global action plan to end statelessness. Paper presented at Symposium on Statelessness, Kenan Institute of Ethics, Duke University.

Robson, G. (2004). A layman looks at the rule of law. Articles 332 Criminal Law and Justice Weekly (formerly Justice of the Peace). Issue 18 (May).

Kofi Annan. (2004). Report of the Security Council on the Rule of Law and Transitional Justice in Conflict and Post Conflict Societies, UN Doc. S/2004/616.

Shklar, J. N., \& Hoffman. S. (Eds.). (1998). Political theory and the rule of law. In Political Thought and Political Thinkers. Chicago: University of Chicago Press.

Tan Tek Seng v Suruhanjaya Perkhidmatan Pendidikan. [1996] 1 MLJ 261. 
Tikamdas, R. (2006). The right to identity and citizenship under the constitution and international law, statelessness: An obstacle to economic empowerment. Paper presented at a Forum by Era Consumer, Kuala Lumpur, 1-5.

Tun Naing Oo v Public Prosecutor [2009] 5 MLJ 680.

UN High Commissioner for Refugees (UNHCR). (2010, May). Expert meeting - The concept of stateless persons under International Law ("Prato Conclusions"). Retrieved from https://www.refworld.org/docid/4calae002.html

United Nations. (1954). Convention relating to the Status of Stateless Persons. 360 U.N.T.S 11. New York: United Nations.

United Nations. (1966). International Covenant on Civil and Political Rights. 999 UNTS 171. New York: United Nations. United Nations. (1979). Convention on the Elimination of All Forms of Discrimination against Women. 1249 UNTS 13. New York: United Nations.

United Nations. (1989). Convention on the Rights of the Child. 1577 UNTS 13. New York: United Nations.

Yaqin, A. (2007). Legal research and writing. Malaysia: LexisNexis. 